\title{
Rapunzel Sendromuna Bağlı İntestinal Obstrüksiyonun Farklı Bir Klinik Sunumu: İshal
}

\section{A Different Clinical Presentation for Intestinal Obstruction due to Rapunzel Syndrome: Diarrhea}

\author{
${ }^{1}$ Aytaç TAŞCI, ${ }^{2}$ Turan YILDIZ \\ ${ }^{1}$ Department of Pediatric Surgery, Sinop Atatürk State Hospital, Sinop, Turkey \\ ${ }^{2}$ Department of Pediatric Surgery, Inonu University Faculty of Medicine, Malatya, Turkey \\ Aytaç Taşc1: https://orcid.org/0000-0002-4024-5219 \\ Turan Yildiz: https://orcid.org/0000-0001-5317-7537
}

\begin{abstract}
ÖZ
Trikobezoar yutulan saç veya saç benzeri maddelerin mide ve/veya ince barsakda birikimine denilir. Midede biriken saç topunun nadiren de olsa piloru geçerek ince barsaklara hatta kolona ulaşmasına Rapunzel sendromu denilmektedir. Klinik bulgular ve tedavi yöntemleri saç topunun büyüklük ve konumuna göre değişmektedir. Literatürde trikobezoarlar hakkında sınırlı sayıda yayın olmak ile beraber trikobezoar nedeniyle gelişen intestinal obstrüksiyon sonrası ishal ile acil servise başvuru hakkında yayın yoktur. Yazımızda acil servisimize Rapunzel sendromuna bağlı intestinal obstrüksiyon sonrası ishal ve kusma ile başvuran bir hastayı sunacağız.

Anahtar Kelimeler: İntestinal obstrüksiyon, Rapunzel sendromu, trikobezoar
\end{abstract}

\begin{abstract}
Trichobezoars are defined as accumulation of hair or hair like substances in the stomach and/or small intestinal. It's called Rapunzel syndrome when the accumulated hair ball pass the pylorus and reaches the small intestines and colon from the stomach. Clinical findings and treatment methods may vary according to the localization and size of the hair ball. In the literature; there are a limited of number publications about trichobezoar and Rapunzel syndrome but there hasn't been a report of intestinal obstruction due to trichobezoar presenting to the emergency department with diarrhea. In this report; we will present a patient who applied to the emergency department with diarrhea and vomiting associated with intestinal obstruction due to Rapunzel syndrome.
\end{abstract}

Keywords: Intestinal obstruction, Rapunzel syndrome, trichobezoars
Sorumlu Yazar / Corresponding Author:

Aytaç Taşci

Sinop Atatürk Devlet Hastanesi, Çocuk Cerrahi Bolumu,

Osmaniye Köyü Tırkışlar Mevkii, Sinop

Tel: +905432248151

E-mail: dr_aytactasci@hotmail.com
Yayın Bilgisi / Article Info:

Gönderi Tarihi/ Received: 21/12/2020

Kabul Tarihi/ Accepted: 06/01/2021

Online Yayın Tarihi/ Published: 05/03/2021

Atıf/ Cited: Taşçı A, Yıldız T. A Different Clinical Presentation for Intestinal Obstruction due to Rapunzel Syndrome: Diarrhea. 2021;6 (1):143-149 . doi: $10.26453 /$ otjhs.844272

\section{INTRODUCTION}

Human hair and hair-like fibers are resistant to digestion and peristalsis due to their smooth and slippery surface, continuous ingestion of them leads to the impaction of together with mucus and food. ${ }^{1}$ This hair ball is called trichobezoar and when trichobezoar migrates to small bowel or colon from pylorus it's call Rapunzel syndrome. ${ }^{2}$ Trichobezoars complications depend on their size, location and chronicity. They usually locate on stomach and rarely migrate small bowel and colon which can cause intestinal obstruction and perforation. ${ }^{1}$

Trichobezoars are associate with some disorders such as obsessive-compulsive disorders, anxiety, depression, mental disorders, abuse, pica and anorexia nevrosa. ${ }^{3-5}$ Although trichobezoar is mostly formed by the person swallowing her own hair (trichophagia), also rarely formed by the ingestion of other family members hair or structures such as doll or pet. ${ }^{5}$ There will be no clinical complaints due 
to hair that starts to accumulate in the stomach during early stages. Growing hair ball can lead to silent symptoms like fatigue, weight loss, nausea, vomiting, intermittent epigastric pain, constipation and diarrhea. ${ }^{1,2}$ Hair ball, increasing in size and weight due to ongoing trichophagia habit, lead to complications like iron deficiency, megaloblastic anemia, hematemesis, protein losing enteropathy, gastric mucosal erosion, gastric outlet and intestinal obstruction, perforation, intussusception, pancreatitis, peritonitis and death. ${ }^{1,2,5,6}$

We aimed to present a case whose first application complaints are diarrhea and vomiting due to trichobezoar obstruction in small bowel.

\section{CASE REPORT}

Informed consent/ consent form was signed by the family and scientific use of patient pictures was allowed. There was no need for the Ethics Committee's Approval.

An 11-year-old girl was apply to the hospital with complaints of bilious vomiting and diarrhea. Laboratory results showed us; haemoglobin concentration: $13.4 \mathrm{~g} / \mathrm{dl}$, white blood cell count: $12.8 \times 10^{3} / \mu \mathrm{l}$ and thrombocyte count was $397 \times 10^{3} /$ L. C-reactive protein (CRP) was $19 \mathrm{mg} / \mathrm{L}$. Biochemical examination was in the normal range. Direct abdominal radiography showed suspicious air-fluid level in the midline of the abdomen, no gas was seen in the colon (Figure-1). Fecal matter exploration was normal. The patient was hospitalized by pediatrician with a pre-diagnosis of gastroenteritis since air fluid levels and diarrhea can be seen as gastroenteritis patients. When bilious vomiting persisted and diarrhea stopped in 24 hours, patient was referred to pediatric surgery. Widespread distension and tenderness in the abdomen were observed in the physical examination of the patient. There was no gas or stool for the last twelve hours. Laboratory investigations showed leukocytosis (WBC:15.38/uL)and hyponatremia $(131 \mathrm{mmol} / \mathrm{L})$ and hypocalcemia $(7.3 \mathrm{mmol} /$ L). C-reactive protein (CRP) was normal range. The patient's abdominal radiography showed sharply limited air-fluid levels in small bowels (Figure-2).

Abdominal ultrasonography showed dilated small intestines in the right upper and lower quadrants and diffuse free fluid in the abdomen. On abdominal tomography jejunal loops were dilated and suspicious organic flammable body obstruction was observed in the upper right part (Figure-3). Urgent laparatomy was performed with midline vertical incision. On exploration, proximal small bowel loops dilated and obstructing intraluminal mass was encountered approximately $80 \mathrm{~cm}$ from duodenojejunal flexure. $3 \mathrm{~cm}$ longitudinal enterotomy was performed on the anti-mesenteric border of the mass (Figure-4). Measuring approximately $8 \times 5 \times 2 \mathrm{~cm}$ hair ball was removed and enterotomy was repaired. All intraabdominal intestinal segments were checked and no other hairballs were found. The patient was discharged on postoperative 5 days with the recommendation of follow-up examination after consultation with child and adolescent psychiatry. The patient, who has no pathology related to pediatric surgery, continues to be followed up and treated in child and adolescent psychiatry.

\section{DISCUSSION AND CONCLUSION}

The masses formed in the gastrointestinal system by ingestion of non-digestible foreign bodies are called bezoars. Bezoars are classified based on their composition like phytobezoar (vegetable or fruit fibers), trichobezoar (human hair), lactobezoars (milk curd), lithobezoars (stones fragments). The incidence of bezoars is not known exactly due to their high prevalence in mentally ill patients but estimated incidence is less than $0.5 \%$ of all esophagogastroduodenoscopies. $^{7}$ It is most common between the ages of $13-20$, and $90 \%$ of the patients are young girls. ${ }^{4}$ The frequency of phytobezoars is higher in some series of endoscopy; counter wisely in some series the most common bezoar type is tricobezoar. $^{1,7}$

Constantly ingested human hair or hair like fibers accumulate in the stomach and become covered with mucus and acid which called trichobezoar. Trichobezoars most common site is stomach but they can rarely migrate to distal intestinal segment from pylorus and called Rapunzel syndrome. ${ }^{2}$ Some psychiatric disorders, mental retardation, child abuse and neglect can accompany to trichobezoars. ${ }^{3,4}$

Unfortunately trichobezoars are have no specific symptoms and signals. Fatigue, weight loss, iron deficiency, megaloblastic anemia, hematemesis, protein losing enteropathy, constipation and diarrhea, gastric mucosal erosion, ulceration are some chronic complication of untreated trichobezoars. $^{1,2,4-7}$ Some acute complications of trichobezoars are intestinal and gastric outlet obstruction, perforation, intussuception. ${ }^{1,5}$ In our case, there was bilious vomiting that started with diarrhea. Although the diarrhea stopped in 12-24 hours, bilious vomiting continued, and the patient was consulted to us. We do not know clearly whether there 
is an obstruction due to the movement of the hairball with diarrhea or whether the diarrhea is due to peritonitis that develops in response to intestinal obstruction. However, the air-fluid level on the radiograph taken in our patient's first visit to the emergency room was persistent in 24 and 48 hours.

The most helpful information in the diagnosis is trichophagia history but in our case child and family denied when we specially asked. At the physical examination an abdominal mass can be palpated but in our case we didn't palpate a mass because of dilated small intestines. Although there isn't a specific laboratory marker to trichobezoar, there may be signs of increased inflammatory markers and anemia. In our case we observed leukocytosis.

Imaging plays a major role in establishing the diagnosis however there is usually no specific finding on the X-ray. In our case we observed the air-fluid level in harmony to gastric obstruction but air fluid levels on the X-ray can be seen in many diseases like gastroenteritis. The most specific finding in barium studies filling defect on stomach. In some cases; abdominal ultrasonography can show pathognomonic shadows between bezoar and bowel. ${ }^{8}$ In particular, contrast-enhanced computed tomography distinguishes the bezoars from intraluminal mass and well-dilated bowel loops as well as from intraluminal tumors and intestinal ischemia. ${ }^{8}$

Treatment options in trichobezoar vary according to the patient's complaints, location and size of the hair ball. Endoscopic intervention rate is around 5\% due to size, density and hardness of the hair ball. ${ }^{4,9}$ Some small volume gastric trichobezoars were successfully removed endoscopically. In some selected cases, agents such as coke were applied endoscopically, in others, the hair ball was cut with the help of endoscopic scissors. ${ }^{10}$ Until now less than ten reports of attempted laparoscopic removal were published thanks to risk of spilling contaminated hair fragments into the abdominal cavity and difficulty to remove the hair ball. ${ }^{3}$ Laparotomy is still first choice of treatment with high effect and low complication rate. ${ }^{6}$ Laparotomy allows a careful examination of the entire gastrointestinal tract. ${ }^{9}$ Pre-discharge child and adolescent psychiatric consultation should be requested in all patients.

We think that in patients presenting with diarrhea and vomiting, if the history of trichophagia is present in anamnesis, it should be careful about trichobezoar complications like intestinal obstruction.
Ethics Committee Approval: Informed consent/ consent form was signed by the family and scientific use of patient pictures was allowed. There was no need for the Ethics Committee's Approval.

Conflict of Interest: No conflict of interest was declared by the authors.

Author Contributions: Concept - AT, TY; Supervision - TY; Materials - AT; Data Collection and Processing - AT, TY; Analysis and Interpretation - TY, AT; Writing - TY AT.

Peer-review: Externally peer-reviewed.

\section{KAYNAKLAR}

1. Gonuguntla V, Joshi DD. Rapunzel syndrome: a comprehensive review of an unusual case of trichobezoar. Clin Med Res. 2009;7:99-102.

2. Naik S, Gupta V, Naik S, Rangole A, Chaudhary AK, Jain P. Rapunzel syndrome reviewed and redefined. Dig Surg. 2007;24:157 -161 .

3. Armstrong JH, Holtzmuller $\mathrm{KC}$, Barcia PJ. Gastric trichobezoar as a manifestation of child abuse. Curr Surg. 2001;58:202-204.

4. Mehta MH, Patel RV. Intussusception and intestinal perforations caused by multiple trichobezoars. J Pediatr Surg. 1992;27:12341235 .

5. Kilincaslan H, Aydoğdu I, Kucukkoc M Osmanoglu NK, Karacanoglu D. Approach to trichobezoar cases in children: Literature review. Bezmialem Science. 2014;2:26-30.

6. Cannalire G, Conti L, Celoni M, et al. Rapunzel syndrome: an infrequent cause of severe iron deficiency anemia and abdominal pain presenting to the pediatric emergency department. BMC Pediatrics. 2018;125:10971098.

7. Erzurumlu K, Malazgirt Z, Bektas A, Dervisoglu A. Gastrointestinal bezoars: A retrospective analysis of 34 cases. World J Gastroenterol. 2005;11(12):1813-1817.

8. Maglinte DD, Heitkamp DE, Howard TJ, Frederick MK. Lappas JC. Current concepts in imaging of small bowel obstruction. Radiol Clin North Am. 2003;41(2):263-283.

9. Tudor ECG, Clark MC. Laparoscopic-assisted removal of gastric trichobezoar; A novel technique to reduce operative complications and time. J. Pediatr. Surg. 2013;48(3):13-15.

10. Gülerman F, Güven B, Demir S, Özmen İ. How should trichobezoar be treated in children? Turk J Gastroenterol. 2019;30(7):660-661. 


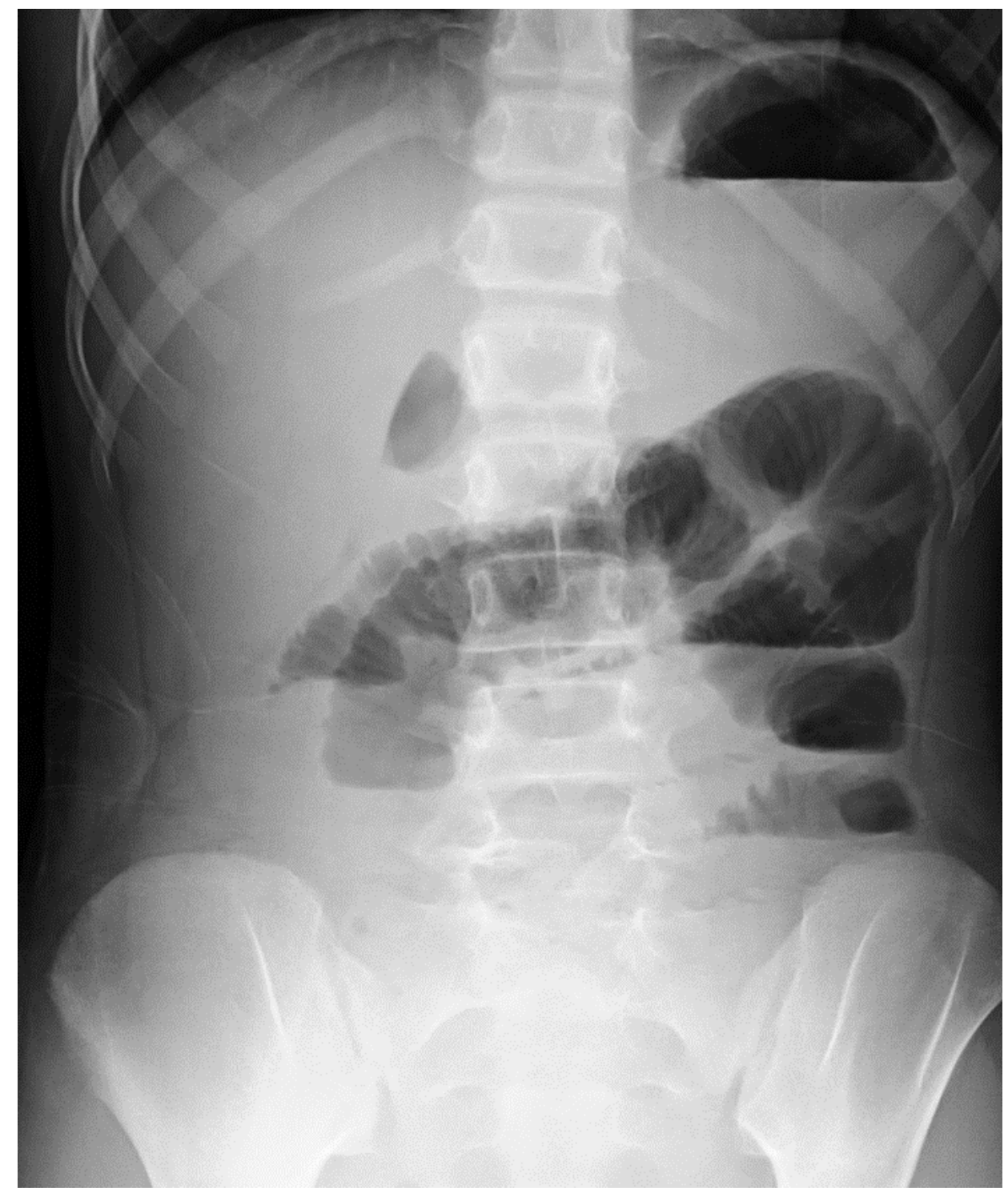

Figure 1. Air fluid levels and no gas in colon, first graphy in emergency department. 


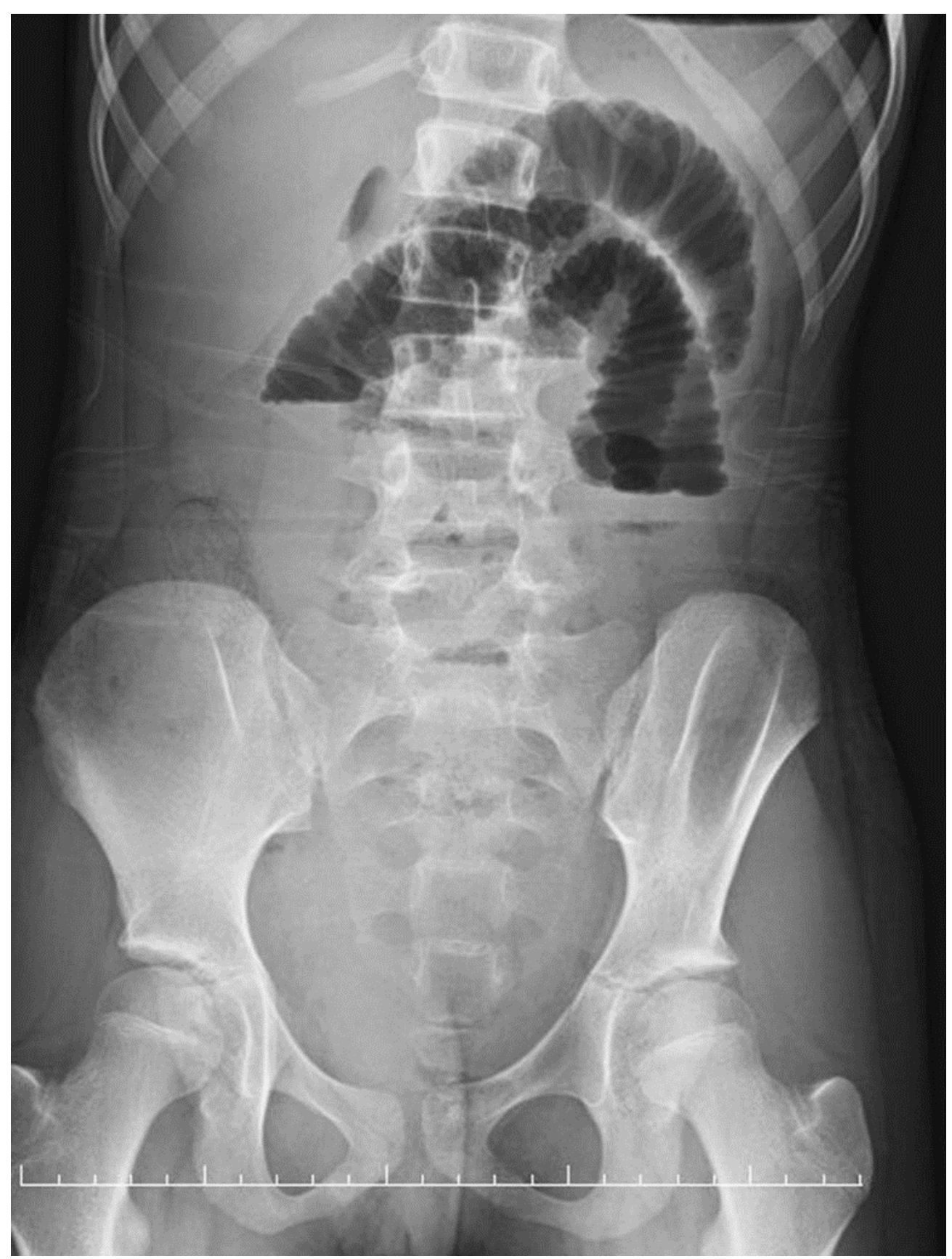

Figure 2. Air fluid levels in small bowels (24 hours later graphy). 


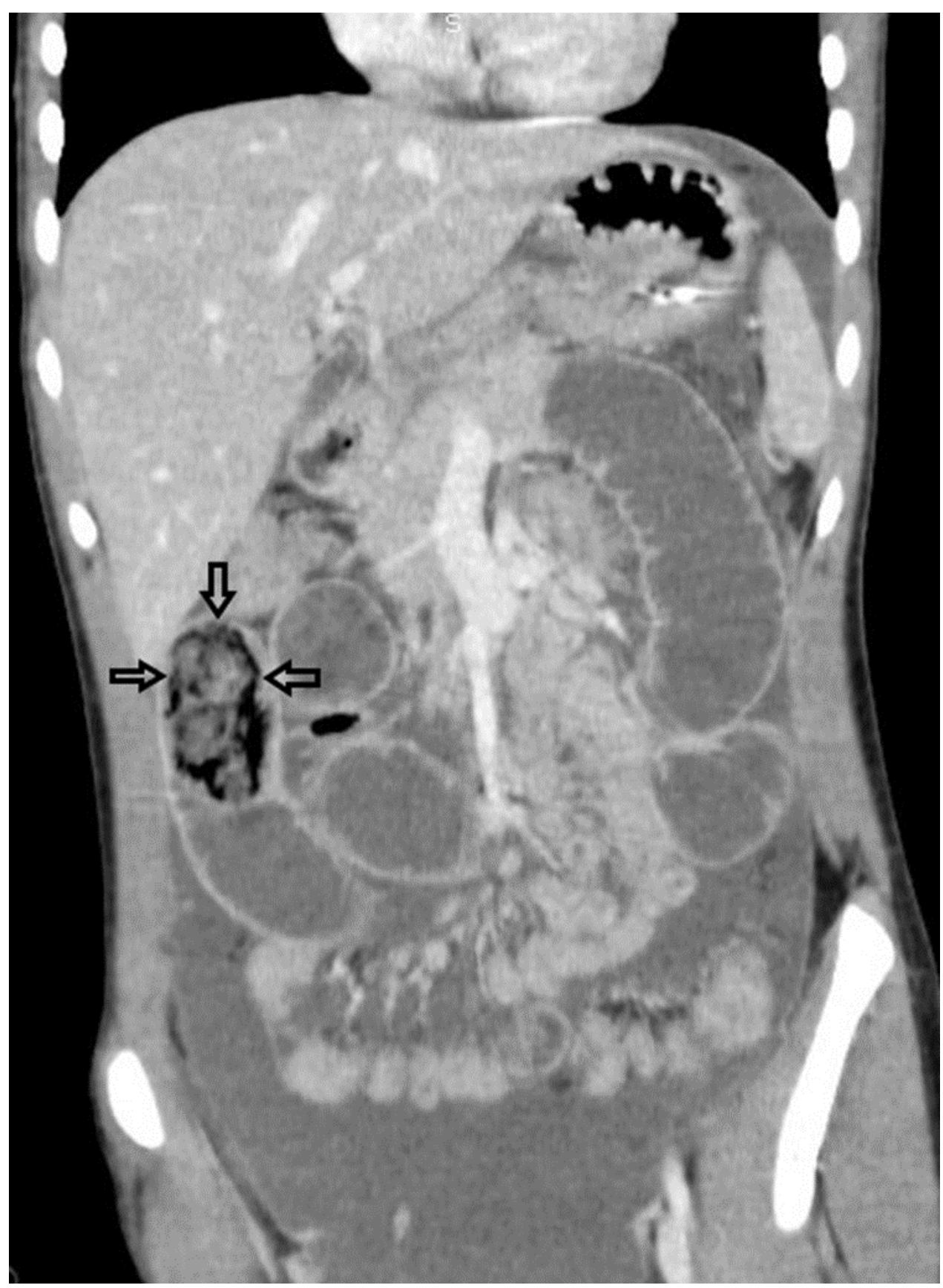

Figure 3. Dilated intestinal loops, free fluid and hair ball. 


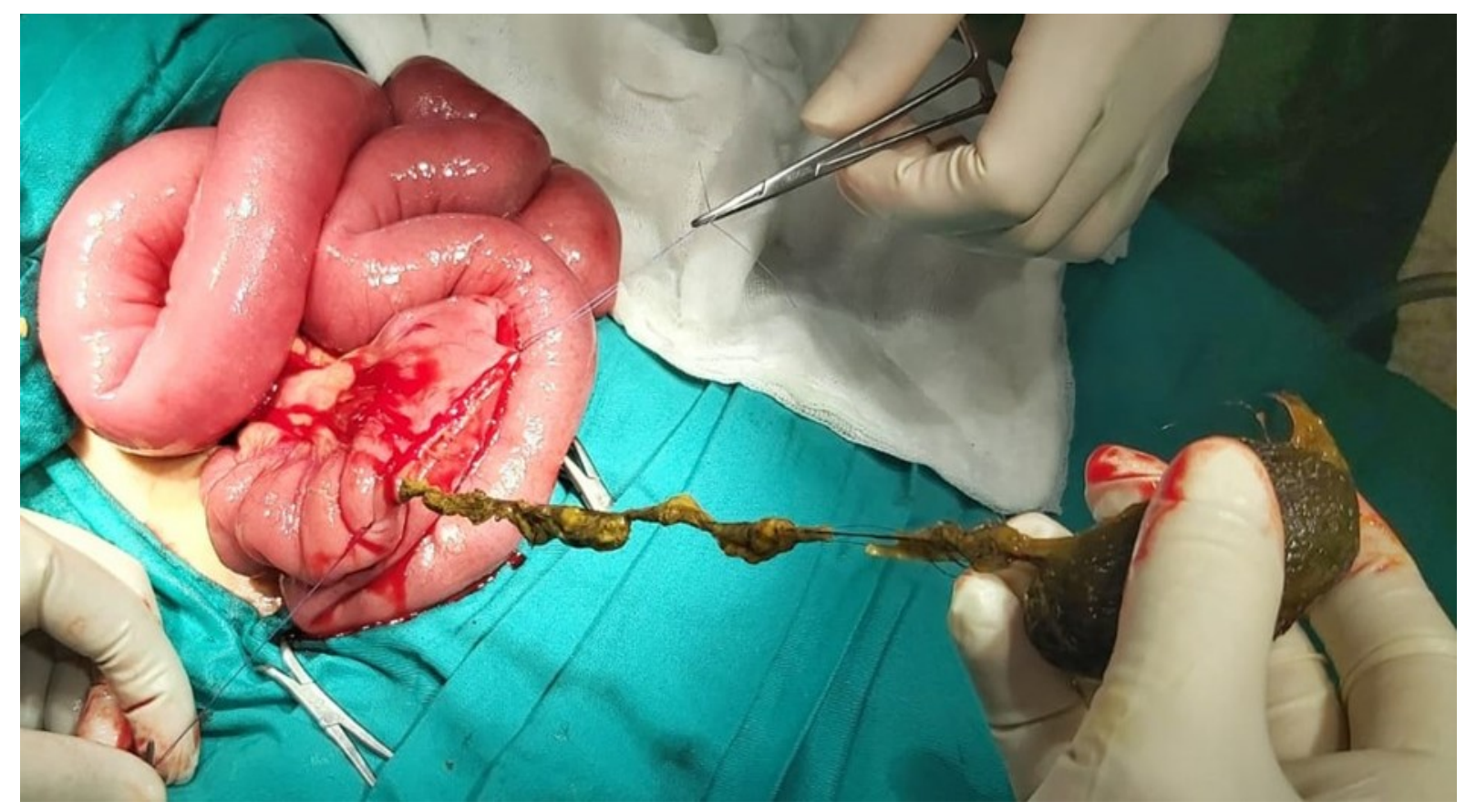

Figure 4. Hair ball in jejunum. 